GEOGRAFICKÝ ČASOPIS / GEOGRAPHICAL JOURNAL 73 (2021) 2, 103-123

DOI: https://doi.org/10.31577/geogrcas.2021.73.2.06

\title{
ELEKTROMOBILITA A JEJ VZŤAH S EKONOMICKÝM ROZVOJOM A ZNEČISTENÍM OVZDUŠIA V PRIESTORE EÚ
}

\author{
Erik Šoltés*, Ivan Brezina**, Juraj Pekár** \\ * Ekonomická univerzita v Bratislave, Fakulta hospodárskej informatiky, Katedra štatistiky, \\ Dolnozemská cesta 1,85235 Bratislava, erik.soltes@euba.sk \\ ** Ekonomická univerzita v Bratislave, Fakulta hospodárskej informatiky, Katedra operačného výskumu \\ a ekonometrie, Dolnozemská cesta 1,852 35 Bratislava, ivan.brezina@euba.sk, juraj.pekar@euba.sk
}

\begin{abstract}
Electromobility and its relationship with the economic development and air pollution in the EU area

The article provides an assessment of 23 out of EU-28 countries in terms of electromobility based on cross-sectional data for 2018, taking into account its relationship with the economic conditions for the development of electromobility and with the air pollution by greenhouse gas emissions in these countries. The paper analyses aggregated statistics provided by Eurostat and ACEA to (1) verify whether they confirm that countries with a higher penetration of electric vehicles in passenger transport have significantly lower greenhouse gas emissions, and (2) in view of the economic maturity of countries, to identify which ones achieve higher and which lower intensity of electromobility. Since the economic conditions and the intensity of electromobility are assessed by several indicators, it was necessary to use multivariate statistical methods, especially factor and cluster analysis, to assess the relationship between these multidimensional phenomena.
\end{abstract}

Key words: electric vehicles, electromobility, economy, greenhouse gas emission, factor analysis, cluster analysis, European Union

\section{ÚVOD}

Klimatické zmeny, vrátane globálneho otepl'ovania, predstavujú vel'ké riziko pre l'udstvo, pretože majú zásadný vplyv na pol’nohospodárstvo, ekosystémy, vznik živelných katastrof, ale aj na l'udské zdravie (Lionello a Scarascia 2018). Tieto klimatické zmeny prekračujú národné hranice, preto je nevyhnutné prijat' účinné opatrenia na zníženie emisií skleníkových plynov (najmä $\mathrm{CO}_{2}$ ), ktoré k týmto zmenám preukázatel'ne prispievajú (Anderson et al. 2016 a Szulejko et al. 2017).

Od roku 1990 do roku 2017 klessli emisie skleníkových plynov (d’alej len ESP) v štátoch Európskej únie (d’alej EÚ-28) o 23,5 \%. Jediným významným hospodárskym odvetvím, v ktorom sa ESP zvýšili, je doprava, pričom toto odvetvie v roku 2017 produkovalo viac ako štvrtinu ESP v EÚ-28 (EEA 2019). Od roku 1990 do roku 2017 sa podarilo znížit ESP z dopravy len dvom krajinám EÚ-28, a to Švédsku a Litve. V priestore EÚ-28 zaznamenalo najväčší nárast ESP z dopravy Pol'sko a zvýšenie na viac ako dvojnásobok pozorujeme aj v Luxembursku, Irsku, Slovinsku a na Malte. V roku 2017 takmer tri štvrtiny ESP z dopravy pripadali na cestnú dopravu, pričom najväčší podiel na tvorbe emisií z dopravy mali osobné automobily. V snahe znižovat' ESP sa v súčasnosti vel'ká nádej vkladá do elektromobility. Uvẹdené skutočnosti nás motivovali $\mathrm{k}$ tomu, aby sme preskúmali, či v priestore EÚ je vyššia intenzita elektromobility preukázatel'ne spojená s menším znečistením ovzdušia ESP. 
Hlavným skleníkovým plynom je oxid uhličitý $\left(\mathrm{CO}_{2}\right)$, preto sa EÚ snaží jeho produkciu znižovat'. Na základe nariadenia Európskeho parlamentu a Rady EÚ 2019/631 budú v EÚ pre nové osobné automobily a l'ahké úžitkové vozidlá platit' prísnejšie emisné normy $\mathrm{CO}_{2}$, a to $95 \mathrm{~g} \mathrm{CO} / \mathrm{km}$. Kým v roku 2020 mal výrobca automobilov dosiahnut' tento ciel' pre $95 \%$ nových automobilov s najnižšími emisiami, tak od roku 2021 sa budú priemerné emisie počítat' zo všetkých nových zaregistrovaných automobilov výrobcu (European Commission 2019).

Napriek tomu, že sa prijali viaceré stratégie, ktoré by mali viest' k znižovaniu ESP pochádzajúcich z dopravy, stále nebol dosiahnutý signifikantný pokrok. Podl’a Transport and Environment (2019) je dôvodov niekol'ko, a to:

- malé zníženie emisií, ktoré sú produkované automobilmi so spal'ovacím motorom. Od roku 2013 do roku 2018 sa emisie z benzínových a dieselových vozidiel znížili len o 4,9 g CO $2 / \mathrm{km}$, resp. 5,3 $\mathrm{g} \mathrm{CO}_{2} / \mathrm{km}$;

- malý podiel vozidiel s nulovými a nízkymi emisiami;

- nárast predaja vozidiel kategórie SUV v Európe zo 7 \% v roku 2009 na 36 \% $\mathrm{v}$ roku 2018.

Pre environmentálnu udržatel'nost' dopravy je nevyhnutná jej dekarbonizácia. Jednou z možností je elektromobilita, ktorá môže reálne prispiet' k ochrane životného prostredia, ku skvalitneniu života (hlavne v mestách), ale bude mat' zásadný vplyv aj na pracovný trh a ekonomiku krajín EÚ. Pozitívne efekty elektromobility na skvalitnenie ovzdušia nie sú síce ešte empiricky potvrdené, ale mnohé vedecké štúdie ukazujú, že elektromobilita môže výrazne prispiet' k ochrane životného prostredia. Casals et al. (2016) zistili, že napriek tomu, že viaceré krajiny Európy majú dobrú štruktúru elektrární (vysoký podiel výroby elektriny z obnovitel'ných zdrojov), tak zavádzanie elektromobility nemá požadovanú intenzitu. Dôvodom je, že poskytujú menej finančných stimulov ako napríklad Nórsko. Moro a Lonza (2018) prostredníctvom metódy well-to-wheels, ktorá uvažuje s uhlíkovou intenzitou od výroby až po jej spotrebu, kvantifikovali, že využívanie elektrických vozidiel namiesto benzínových a naftových vozidiel môže ušetrit' okolo $60 \%$, resp. 50 \% ESP vo väčšine štátov EÚ.

Článok sa zameriava na analýzu elektromobility v priestore EÚ, ktorej primárnym ciel'om je zodpovedat' tieto dve výskumné otázky:

- Potvrdzujú aktuálne agregované štatistiky, že v priestore EÚ majú krajiny s vyšším podielom elektricky nabíjatel'ných vozidiel a hybridných elektrických vozidiel v osobnej doprave signifikantne nižšie znečistenie ovzdušia emisiami skleníkových plynov?

- Je intenzita elektromobility v krajinách EÚ preukázatel'ne ovplyvnená ekonomickou vyspelost'ou?

Zámerom našej štúdie bolo navyše odhalit' vzt'ahy medzi tromi dimenziami: intenzita elektromobility, ekonomické predpoklady na rozvoj elektromobility a znečistenie ovzdušia emisiami skleníkových plynov. Z tohto zámeru pramenia tieto ciele:

- posúdit',vzt'ahy medzi uvedenými dimenziami na základe empirických údajov za krajiny EÚ,

- odhalit' podobnosti a odlišnosti krajín EÚ v elektromobilite,

- zhodnotit', ktoré krajiny EÚ doposial' využili svoje ekonomické predpoklady na rozvoj elektromobility lepšie a ktoré naopak v tejto oblasti zaostávajú. 
$\mathrm{Na}$ zodpovedanie uvedených výskumných otázok a na dosiahnutie uvedených ciel'ov sú v článku využité najmä viacrozmerné štatistické metódy, ktoré sú aplikované prostredníctvom štatisticko-analytického softvéru SAS.

\section{ELEKTROMOBILITA V EURÓPE A POZNATKY O FAKTOROCH, KTORÉ JU OVPLVŇUJÚ}

Asociácia európskych automobilových výrobcov ACEA rozdel'uje trh elektrických vozidiel (EV - electric vehicles) do dvoch hlavných kategórií:

- Elektricky nabíjatel'né vozidlá (ECV - electrically-chargeable vehicles), ktoré zahŕn̆ajú elektrické vozidlá s batériou (BEV - battery electric vehicles) a plug-in hybridy (PHEV - plug-in hybrid electric vehicles). BEV využívajú na pohon výlučne elektromotor, pričom elektrickú energiu získavajú primárne z dobíjacích staníc a uchovávajú ju v batériách. BEV nie sú vybavené palivovou nádržou. PHEV majú palivovú nádrž a batériu, ktorú možno priamo nabíjat'. Pri nedostatku energie je batéria v PHEV dobíjaná spal'ovacím motorom.

- Hybridné elektrické vozidlá (HEV) sú poháňané spal'ovacím motorom (benzínovým alebo naftovým), ale majú tiež elektrický motor napájaný z batérie, ktorý slúži na doplnenie konvenčného motora. Ich elektrina sa vyrába interne, takže nepotrebujú dobíjaciu infraštruktúru.

Odborníci sa zhodujú, že proces dekarbonizácie automobilov v Európe sa rozbieha pomaly a podiel ECV a HEV na celkovom počte vozidiel je vel'mi nízky. Podl'a ACEA (2019a) bol v Európe v roku 2018 medzi zaregistrovanými osobnými automobilmi najväčší podiel EV v Nórsku $(10,7 \%)$, za ktorým nasledujú Holandsko $(1,6 \%)$ a Švédsko $(1,3 \%)$. V uvedených krajinách pozorujeme aj najväčší podiel HEV. Ak sa pozrieme na využívané palivo medzi novými osobnými vozidlami (obr. 1), tak dominancia Nórska v elektromobilite sa ešte podčiarkuje.

Nórsko má najväčšie finančné stimuly orientované na zákazníka EV (EASAC 2019). Lévay et al. (2017) zistili, že už v roku 2014 malo Nórsko také fiškálne stimuly, vd’aka ktorým boli EV z pohl'adu celkových nákladov na vlastníctvo automobilu konkurencieschopné vozidlám so spal'ovacím motorom. V ostatných siedmich krajinách, ktoré analyzovali, bola väčšina elektromobilov stále nákladnejšia ako ich páry so spal'ovacím motorom. Autori tohto výskumu ukázali, že malé, stredné a vel'ké vozidlá vykazujú odlišné vzt'ahy medzi predajom a celkovými nákladmi na vlastníctvo automobilu a že tieto rozdiely treba zohl'adnit' pri finančných stimuloch. Broadbent et al. (2018) identifikovali relevantné faktory ovplyvňujúce mieru penetrácie EV. Zistili, že aj ked' je cenová dostupnost' EV pre väčšinu spotrebitel'ov mimoriadne dôležitá, tak s poklesom cien EV sa bude v blízkej budúcnosti dôležitost' vládnych dotácí́ na nákup EV znižovat'. Naopak, bude narastat' význam d’alších faktorov, ako sú adekvátna verejná siet' nabíjacích staníc, poskytovanie aktuálnych informácií o EV (napr. prostredníctvom smartfónových aplikácií s mapami dobíjacích staníc) alebo mäkké stimuly (napr. odpustenie dial'ničného mýta, elektrická energia vo verejných nabíjacích staniciach zadarmo a pod.). Vilchez a Thiel (2019) však na základe výsledkov simulačného modelu zistili, že napriek priaznivému vývoju cien batérií zatial' stále zostávajú najúčinnejším opatrením na podporu elektromobility dotácie na nákup EV. Regresnou analýzou empirických údajov z 32 európskych krajín za obdobie rokov 2010 až 2017 Münzel et al. (2019) kvantifikovali, že za podmienky ceteris paribus zvýšenie finančných stimulov o 1000 eur spôsobí nárast podielu predaja ECV v relatívnom vyjadrení o 5 až $7 \%$. 


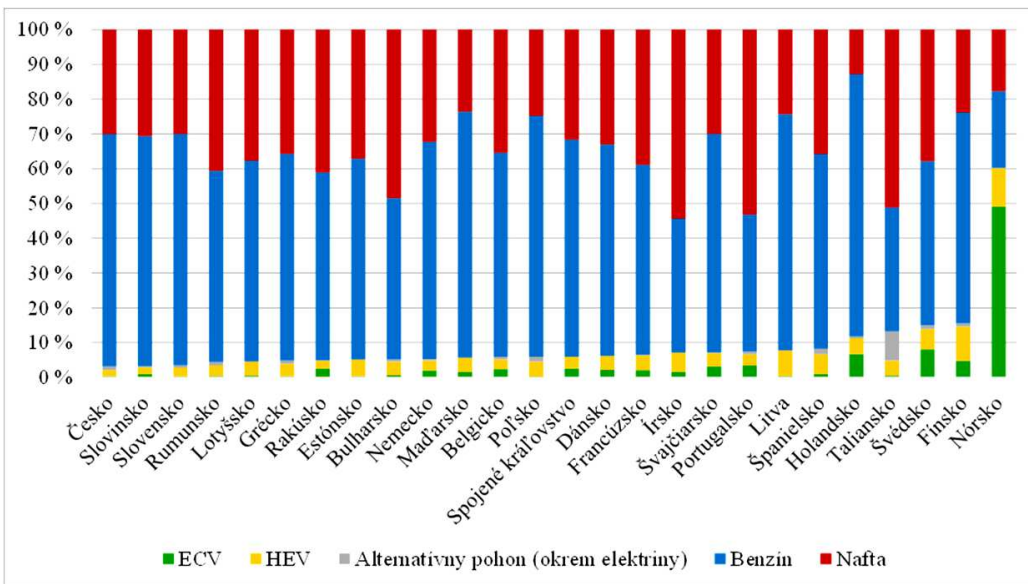

Obr. 1. Zastúpenie jednotlivých typov paliva vo vozovom parku nových automobilov vo vybraných krajinách Európy v roku 2018

Vysvetlivky: ECV - elektricky nabíjatel'né vozidlá, HEV - hybridné elektrické vozidlá. Zdroj údajov: ACEA (2019a).

Mimoriadne dôležitým aspektom pre zvýšenie elektromobility je postoj zákazníkov. Sovacool et al. (2019) prostredníctvom prieskumu v severských štátoch zistili, že nesúlad medzi skutočným vlastníctvom EV a preferenciami takéhoto typu osobnej dopravy pramení z podmienok na trhu automobilov. Kým vo Švédsku sú to relatívne nízke ceny automobilov, v Nórsku je to relatívne vysoká úroveň príjmov a finančné stimuly na nákup EV, vo Fínsku je to pomerne nízka úroveň príjmov a na Islande je to pocit'ovaná závislost' od fosílnych palív. Ortar a Ryghaug (2019) analýzou online diskusií identifikovali problémy, ktoré laická verejnost' vidí pri prechode na EV. Ide najmä o sociálnu a priestorovú nerovnost' využívania EV v každodennom živote a environmentálne vplyvy EV (recyklácia batérií a zvýšená potreba nových nerastných surovín na ich výrobu). Význam názorov spotrebitelov na rozvoj trhu s EV si uvedomujú aj Noel et al. (2020), ktorí využili zhlukovú analýzu pri identifikácii bariér, ako sú napr. dojazd a cena EV, infraštruktúra verejných nabíjacích staníc, ktoré odrádzajú potenciálnych vlastníkov EV od ich kúpy. Christidis a Focas (2019) prostredníctvom klasifikačných stromov zistili, že sklon k nákupu EV silno koreluje s príjmom, dosiahnutým vzdelaním a stupňom urbanizácie a že v období rokov 2014 - 2018 pozitívny postoj ku kúpe EV signifikantne vzrástol vo všetkých sociálno-ekonomických skupinách obyvatel'stva.

Pre nárast elektromobility sú potrebné aj koordinované politické opatrenia, avšak niektoré krajiny majú v tejto oblasti málo ambiciózne ciele (Transport and Environment 2020). Thiel e al, (2019) odhalili, že ak by sa naplnili národné politické rámce členských štátov EÚ, tak podiel EV na celkovom počte osobných vozidiel by sa v EÚ zvýšil len o 1,2\%.

\section{ZDROJE ÚDAJOV A POUŽITÉ METÓDY}

Výsledky vlastného výskumu prezentovaného v článku sú založené na časovo a medzinárodne porovnatel'ných údajoch, ktoré zverejňuje Eurostat a asociácia ACEA. Vychádzame z troch skupín ukazovatel'ov. Prvou sú ukazovatele odzrkadl'ujúce ekonomické predpoklady krajín na elektromobilitu: 
- HDP na obyvatel'a v parite kúpnej sily (v \%; EÚ27 2020=100 \%) HDP obyv,

- výdavky na výskum a vývoj (v eur/obyvatela) - VaV,

- priemerný vek osobných automobilov (v rokoch) - Priemerný_vek.

Výber uvedených ukazovatel'ov je podporený niektorými vedeckými štúdiami. Yong a Park (2017) považujú ekonomickú vyspelost' krajiny meranú HDP na obyvatel'a za dôležitý faktor ovplyvňujúci intenzitu elektromobility. Podl'a Ajanovica a Hassa (2016) je ochota platit' za EV vyššia v krajinách s vyšším HDP na obyvatel'a. Predpokladáme, že nielen súčasná ekonomická vyspelost' krajiny, ale aj budúci vývoj v oblasti hospodárskeho rastu bude mat’ zásadný vplyv na elektromobilitu. Z dlhodobého hladiska je ekonomický rast signifikantne pozitívne ovplyvnený výdavkami krajiny na vedu a výskum (pozri napr. Yazgan a Yalçinkaya 2018). Práve preto vstupujú do našej analýzy ako d’alší ukazovatel' výdavky na výskum a vývoj prepočítané na obyvatela. Tretím ukazovatel'om je priemerný vek osobných automobilov. Ide o indikátor, ktorý prepája dimenziu ekonomických predpokladov a dimenziu znečistenia ovzdušia emisiami. Navyše v krajinách, kde je nižší priemerný vek automobilov, sa vozový park rýchlejšie obmieňa, a teda môže dôjst' $\mathrm{k}$ rýchlejšiemu nahradeniu automobilov využívajúcich fosílne palivá elektromobilmi, prípadne vozidlami na alternatívny pohon. Tucki et al. (2019) predpokladajú, že tento ukazovatel' je zásadný pri prognózovaní ESP vyprodukovaných automobilovou dopravou, a preto ho použili pri predikcii priemernej ročnej produkcie emisií $\mathrm{CO}_{2}$ na $1 \mathrm{~km}$ na území EÚ, Nórska a Svajčiarska.

Druhú skupinu tvoria charakteristiky intenzity elektromobility medzi osobnými automobilmi:

- podiel ECV medzi osobnými automobilmi (v \%) - ECV,

- podiel HEV medzi osobnými automobilmi (v \%) - HEV,

- podiel ECV medzi novými osobnými automobilmi (v \%) - ECV_nové,

- podiel HEV medzi novými osobnými automobilmi (v \%) - HEV_nové.

Tretiu skupinu tvoria ukazovatele znečistenia ovzdušia emisiami:

- ESP v ovzduši $\left(\mathrm{CO}_{2}, \mathrm{~N}_{2} \mathrm{O}\right.$ a $\mathrm{CH}_{4}$ v jednotkách $\mathrm{CO}_{2}$ ekvivalentu; v g/osobu) ESP_celkové_obyv,

- ESP v ovzduší z prepravných aktivít $\left(\mathrm{CO}_{2}, \mathrm{~N}_{2} \mathrm{O}\right.$ a $\mathrm{CH}_{4} \mathrm{v}$ jednotkách $\mathrm{CO}_{2}$ ekvivalentu; v g/osobu) - ESP_preprava_obyv,

- emisie $\mathrm{CO}_{2}$ v ovzduší (v g/osobu) - $\mathrm{CO}_{2}$ celkové_obyv,

- emisie $\mathrm{CO}_{2} \mathrm{v}$ ovzduší z prepravných aktivít (v g/osobu) - $\mathrm{CO}_{2}$ preprava_obyv,

- priemerné emisie $\mathrm{CO}_{2} \mathrm{z}$ nových automobilov $\left(\mathrm{v} \mathrm{g} \mathrm{CO}_{2} / \mathrm{km}\right)-\mathrm{CO}_{2}$ nové.

Uvedené ukazovatele sú analyzované za rok 2018 (najnovšie dostupné údaje) pre skupinu týchto 23 krajín EÚ-28: Belgicko (BE), Cesko (CZ), Dánsko (DK), Nemecko (DE), Estónsko (EE), Írsko (IE), Grécko (EL), Śpanielsko (ES), Francúzsko (FR), Taliansko (IT), Lotyšsko (LV), Litva (LT), Mad’arsko (HU), Holandsko (NL), Rakúsko (AT), Pol'sko (PL), Portugalsko (PT), Rumunsko (RO), Slovinsko (SI), Slovensko (SK), Fínsko (FI), Švédsko (SE) a Spojené král'ovstvo (UK). $Z$ dôvodu nedostupnosti aktuálnych údajov neboli do analýzy zahrnuté tieto krajiny EÚ-28: Bulharsko, Cyprus, Chorvátsko, Luxembursko a Malta. 
Na dosiahnutie ciel’ov je aplikovaná korelačná, regresná, faktorová a zhluková analýza. Korelačná analýza (pozri napr. Šoltés 2019) je použitá na overenie závislosti medzi vstupnými ukazovatel'mi. V našom výskume pôvodné ukazovatele transformujeme na lineárne nezávislé faktory, a to prostredníctvom faktorovej analýzy (pozri napr. Hair et al. 2018), výsledkom ktorej je redukcia pôvodného počtu premenných a vytvorenie nových dimenzií - faktorov, ktorými hodnotíme elektromobilitu. Výsledky faktorovej analýzy sú v článku kl’účové pre zhlukovú analýzu (pozri napr. Hair et al. 2018 a Reiff et al. 2018), prostredníctvom ktorej sa objekty (v našom prípade 23 krajín EÚ) spájajú do zhlukov tak, aby objekty patriace do toho istého zhluku boli podobné (blízke) a objekty patriace do rôznych zhlukov boli odlišné (vzdialené). Na meranie podobnosti objektov v jednotlivých zhlukoch využívame štvorec euklidovskej vzdialenosti. V článku aplikujeme Wardovu hierarchickú metódu zhlukovania, ktorá vytvára zhluky maximalizáciou vnútrozhlukovej homogenity (Reiff et al. 2016), a má tendenciu spájat' zhluky s malým počtom pozorovaní a konzistentne dosahuje výborné výsledky (Löster a Pavelka 2013). Na prepojenie výsledkov faktorovej analýzy a zhlukovej analýzy využívame aj jednoduchú lineárnu regresiu (pozri napr. Soltés 2019).

\section{ANALÝZA VHODNOSTI A TRANSFORMÁCIA VSTUPNÝCH ÚDAJOV}

Ked’že jedným z nástrojov na dosiahnutie ciel'ov výskumu bola zhluková analýza, ktorá predpokladá nezávislost' vstupných premenných, tak pôvodnú množinu korelovaných ukazovatel'ov sme museli transformovat' na lineárne nezávislé premenné. Na tento účel bola využitá faktorová analýza. Na posúdenie vhodnosti zdrojových ukazovatel'ov poslúžila Kaiser-Meyer-Olkinova miera, ktorej hodnoty nad úrovňou 0,5 (pozri napr. Vojtková a Stankovičová 2020) identifikovali z pôvodnej množiny 12 ukazovatel'ov 7 ukazovatel'ov (tab. 1) vhodných na d'alšiu analýzu.

Tab. 1. Hodnoty Kaiser-Meyer-Olkinovej miery pre vybrané ukazovatele

\begin{tabular}{ccccccc}
\hline \multicolumn{7}{c}{ Kaiser-Meyer-Olkinová miera výberovej vhodnosti: Celkové MSA $=0,7509$} \\
\hline VaV & ECV_nové & ECV & HEV & Priemerný_vek & HDP_obyv & ESP_preprava_obyv \\
\hline 0,7826 & 0,7913 & 0,6918 & 0,6892 & 0,7980 & 0,7659 & 0,6550 \\
\hline
\end{tabular}

Zdroj: Eurostat (2020) a ACEA (2019a), vlastné spracovanie v SAS Enterprise Guide.

Pretože premenné vstupujúce do faktorovej analýzy by mali byt’ navzájom lineárne závislé (Vojtková a Stankovičová 2020, pp. 92 - 93), tak prostredníctvom korelačnej analýzy sme ešte posúdili intenzitu (obr. 2) a štatistickú významnost' (tab. 2) závislosti medzi všetkými dvojicami vybraných siedmich ukazovatel'ov.

V silnej priamej korelácii sú HDP na obyvatel'a a výdavky na výskum a vývoj prepočítané na jedného obyvatel'a príslušnej krajiny. Priemerný vek osobných automobilov je v nepriamej lineárnej závislosti so všetkými posudzovanými ukazovatel'mi, pričom je v najtesnejšom vzt'ahu s HDP na obyvatel'a a výdavkami na výskum a vývoj. Podiel ECV a podiel HEV v skupine osobných automobilov, ako aj podiel ECV medzi novými osobnými automobilmi, sú v silnom priamom lineárnom vzt’ahu. Najslabšie korelácie pozorujeme pre jediný indikátor kvality ovzdušia (ESP_preprava_obyv). Matica p-hodnôt pre test štatistickej významnosti korelácie 
medzi uvedenými siedmimi ukazovatel'mi (tab. 2) však odhalila, že ukazovatel' ESP preprava_obyv nie je na hladine významnosti 0,05 signifikantne korelovaný so žiadnym z ostatných šiestich ukazovatel'ov (všetkých šest' $p$-hodnôt je väčších ako hladina významnosti 0,05 ). Toto zistenie je v súlade so zisteniami iných prác (EASAC 2019 a Gryparis et al. 2020), podl'a ktorých vplyv elektromobility na zlepšenie kvality ovzdušia v EÚ zatial' nie je empiricky preukázatel'ný. Dôvodom je nízka intenzita elektromobility, ako aj významný podiel elektrární založených na fosílnych palivách.

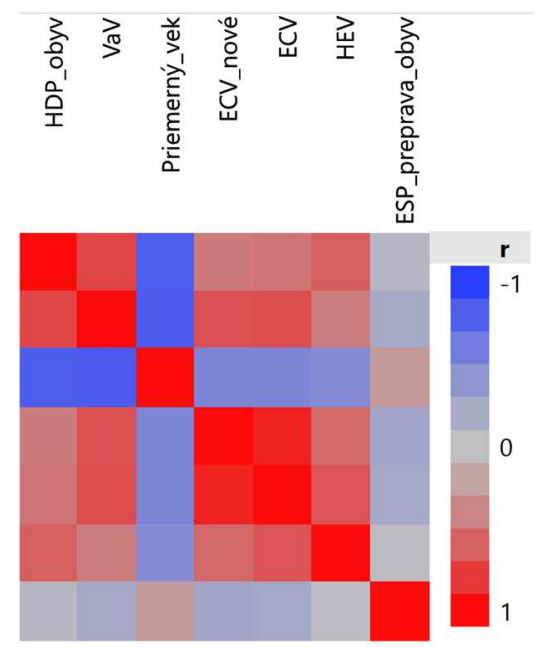

Obr. 2. Korelačná matica vybraných ukazovatel'ov

Zdroj: Eurostat (2020) a ACEA (2019a), vlastné spracovanie v SAS JMP.

Tab. 2. Matica p-hodnôt pre test štatistickej významnosti koeficienta korelácie medzi dvojicami vybraných ukazovatel'ov

\begin{tabular}{|c|c|c|c|c|c|c|c|}
\hline & $\begin{array}{l}\text { HDP } \\
\text { obyv }\end{array}$ & $\mathrm{VaV}$ & $\begin{array}{l}\text { Priemerný } \\
\text { vek }\end{array}$ & $\begin{array}{l}E C V_{-} \\
\text {nové }\end{array}$ & $E C V$ & $H E V$ & $\begin{array}{c}\text { ESP_preprava } \\
\text { obyv }\end{array}$ \\
\hline HDP_obyv & $<, 0001$ & $<, 0001$ & $<, 0001$ & 0,0258 & 0,0168 & 0,0018 & 0,6783 \\
\hline $\mathrm{VaV}$ & $<, 0001$ & $<, 0001$ & $<, 0001$ & 0,0004 & 0,0002 & 0,0305 & 0,3192 \\
\hline Priemerný_vek & $<, 0001$ & $<, 0001$ & $<, 0001$ & 0,0101 & 0,0107 & 0,0241 & 0,1989 \\
\hline ECV_nové & 0,0258 & 0,0004 & 0,0101 & $<, 0001$ & $<, 0001$ & 0,0060 & 0,2520 \\
\hline$E C V$ & 0,0168 & 0,0002 & 0,0107 & $<, 0001$ & $<, 0001$ & 0,0005 & 0,2957 \\
\hline$H E V$ & 0,0018 & 0,0305 & 0,0241 & 0,0060 & 0,0005 & $<, 0001$ & 0,8228 \\
\hline $\begin{array}{l}E S P \\
\text { preprava_obyv }\end{array}$ & 0,6783 & 0,3192 & 0,1989 & 0,2520 & 0,2957 & 0,8228 & $<, 0001$ \\
\hline
\end{tabular}

Zdroj: Eurostat (2020) a ACEA (2019a), vlastné výpočty v SAS JMP.

Ďalej budeme uvažovat' so šiestimi závislými ukazovatel'mi, ktorých vhodnost' pre účely faktorovej analýzy potvrdzujú hodnoty Kaiser-Meyer-Olkinovej miery (tab. 3). Jej priemerná hodnota 0,7536 poukazuje na nadpriemerne dobrú vhodnost'. Na základe parciálnych hodnôt tejto miery je vhodnost' jednotlivých ukazovatel'ov 
na priemernej (v prípade ECV a HEV) a na nadpriemerne dobrej úrovni (pozri napr. Vojtková a Stankovičová 2020).

Tab. 3. Hodnoty Kaiser-Meyer-Olkinovej miery pre vybrané ukazovatele

\begin{tabular}{cccccc}
\hline \multicolumn{6}{c}{ Kaiser-Meyer-Olkinova miera výberovej vhodnosti: Celkové MSA $=0,7536$} \\
\hline VaV & ECV_nové & ECV & HEV & Priemerný_vek & HDP_obyv \\
\hline 0,7808 & 0,7825 & 0,6873 & 0,6876 & 0,8254 & 0,7638 \\
\hline
\end{tabular}

Zdroj: Eurostat (2020) a ACEA (2019a), vlastné spracovanie v SAS Enterprise Guide.

Naším ciel'om vo faktorovej analýze je z množiny šiestich vybraných ukazovatel’ov vytvorit' lineárne nezávislé faktory, ktoré budú z hl'adiska elektromobility primerane interpretovatel'né a ktoré v sebe zahrnú aspoň $80 \%$ informácií poskytovaných pôvodnými šiestimi ukazovatel'mi. Túto podmienku splńajú už prvé dva faktory, ktoré sú podl'a tab. 4 (stípec Kumulatívne percento) nositel'mi 83,8 \% pôvodných informácií. Navyše obidva faktory sú signifikantné na hladine významnosti 0,01 , čo potvrdzujú $p$-hodnoty uvedené $\mathrm{v}$ poslednom stípci tab. 4 $(p<0,0001, p=0,0003)$, ktoré sú menšie ako hladina významnosti $\alpha=0,01$.

Tab. 4. Vlastné čísla korelačnej matice a overenie štatistickej významnosti faktorov

\begin{tabular}{ccrrrrr}
\hline Počet & $\begin{array}{c}\text { Vlastné } \\
\text { č́slo }\end{array}$ & Percento & $\begin{array}{c}\text { Kumulatívne } \\
\text { percento }\end{array}$ & Chí-kvadrát & $\begin{array}{c}\text { Stupne } \\
\text { volnosti }\end{array}$ & p-hodnota \\
\hline 1 & 4,1430 & 69,050 & 69,050 & 112,822 & 13,959 & $<, 0001$ \\
2 & 0,8859 & 14,765 & 83,815 & 40,239 & 14,341 & 0,0003 \\
3 & 0,5960 & 9,933 & 93,748 & 23,208 & 10,036 & 0,0102 \\
4 & 0,1572 & 2,620 & 96,368 & 2,540 & 6,258 & 0,8823 \\
5 & 0,1415 & 2,358 & 98,726 & 1,633 & 2,068 & 0,4578 \\
6 & 0,0764 & 1,274 & 100,000 &. &. &. \\
\hline
\end{tabular}

Zdroj: Eurostat (2020) a ACEA (2019a), vlastné výpočty v SAS JMP.

Z faktorových váh (pozri napr. Lubyová a Vojtková 2014) uvedených v tab. 5 môžeme vidiet', $v$ akej korelácii sú pôvodné premenné s rotovanými faktormi. Prvý faktor je v najtesnejšom vzt'ahu s ukazovatel'mi $E C V, E C V$ nové a $H E V$, čo potvrdzujú vypočítané koeficienty korelácie $(0,9605 ; 0,8414 ; 0,5968)$. Na základe uvedeného môžeme povedat', že 1. faktor charakterizuje intenzitu elektromobility v sledovaných krajinách EÚ. Všimnime si, že ukazovatele charakterizujúce zastúpenie elektricky nabíjatel'ných vozidiel (ECV a ECV nové) podstatne silnejšie korelujú s 1. faktorom ako podiel HEV. Druhý faktor je silne korelovaný s HDP na obyvatel'a a s výdavkami na výskum a vývoj. Avšak tento faktor je najväčšou mierou determinovaný priemerným vekom osobných automobilov, pričom $\mathrm{v}$ tomto prípade ide o nepriamu koreláciu $(-0,9032)$. Kým v prípade ukazovatel’ov - HDP na obyvatel'a a výdavky na výskum a vývoj - je žiaduce dosiahnut' čo najvyššie hodnoty, tak priemerný vek osobných automobilov by mal byt' čo najnižší, pretože ten korešponduje s lepšou finančnou situáciou v príslušnej krajine a zároveň vytvára predpoklady na rýchlejšiu obnovu vozového parku, čo je dôležitý atribút pre 
rýchlost' procesu elektromobility. Vzhl'adom na determinujúce ukazovatele (vrátane ich smeru závislosti) môžeme 2. faktor označit' ako faktor ekonomických predpokladov na rozvoj elektromobility. Za zmienku ešte stojí zistenie, že ukazovatel' výdavky na výskum a vývoj významne determinuje nielen 2. faktor (faktorová váha ukazovatel'a $V a V$ je 0,7426), ale aj 1. faktor (faktorová váha $0,5109)$.

Tab. 5. Faktorové váhy po rotácii metódou equamax

\begin{tabular}{lrr}
\hline & Faktor 1 & Faktor 2 \\
\hline HDP_obyv & 0,2795 & 0,8073 \\
VaV & 0,5109 & 0,7426 \\
Priemerný_vek & $-0,2812$ & $-0,9032$ \\
ECV_nové & 0,8414 & 0,3144 \\
ECV & 0,9605 & 0,2783 \\
$H E V$ & 0,5968 & 0,3454 \\
\hline
\end{tabular}

Zdroj: Eurostat (2020) a ACEA (2019a), vlastné výpočty v SAS JMP.

\section{VÝSLEDKY}

$\mathrm{Z}$ interpretácie faktorov, ktorú sme uviedli v predchádzajúcej časti článku, je zrejmé, že je žiaduce, aby obidva faktory dosahovali čo najvyššiu hodnotu. Potom teplotné mapy na obr. 3 ukazujú, akú intenzitu elektromobility (1. faktor; obr. 3 vl'avo) a aké ekonomické predpoklady na elektromobilitu (2. faktor; obr. 3 vpravo) mali posudzované krajiny v roku 2018.
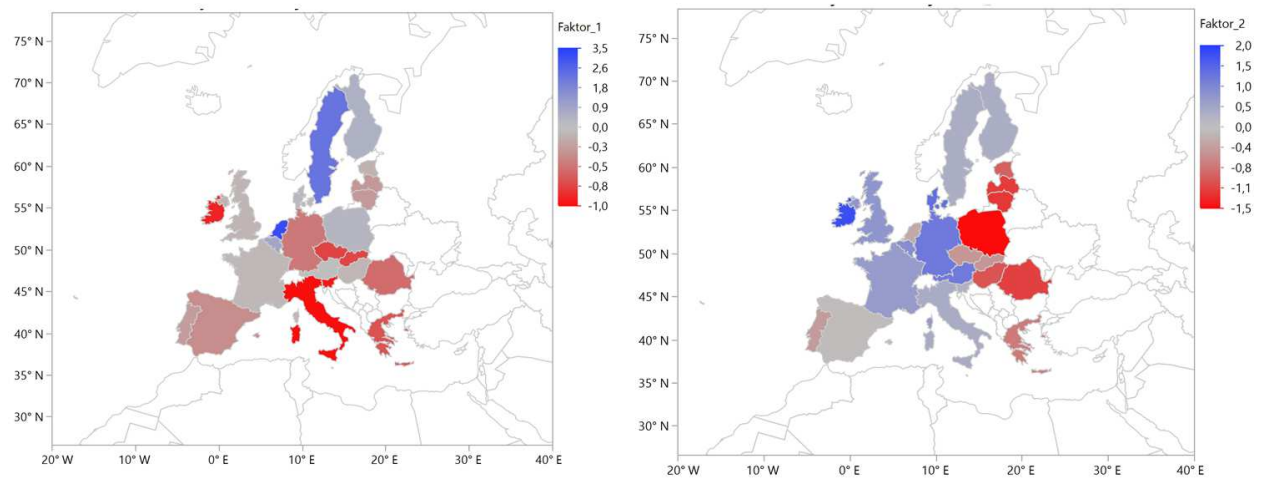

Obr. 3. Mapa intenzity elektromobility (vl’avo) a ekonomických predpokladov na rozvoj elektromobility (vpravo) pre vybrané krajiny EÚ v roku 2018

Zdroj: Eurostat (2020) a ACEA (2019a), vlastné spracovanie v SAS JMP.

V roku 2018 mali z analyzovaných krajín najvyššiu intenzitu elektromobility Holandsko a Švédsko. Za nimi je s vel'kým odstupom Belgicko a Fínsko. Najnižšiu intenzitu elektromobility sme odhalili v Írsku, Slovinsku a Taliansku, za ktorými nasleduje Česko, Slovensko a Grécko. Nízke hodnoty však evidujeme aj v Rumunsku, Nemecku, Španielsku, v pobaltských krajinách (mierne vyššie hodnoty sú 
v Estónsku) a Portugalsku. Podl'a hodnôt 2. faktora (obr. 3 vpravo) mnohé krajiny, ktoré dosahovali v roku 2018 slabú intenzitu elektromobility, mali dobré ekonomické predpoklady na jej rozvoj. Do tejto kategórie patria najmä Írsko a Nemecko. Najhoršie ekonomické predpoklady na rozvoj elektromobility dosahovalo $\mathrm{v}$ roku 2018 Pol'sko, nasledované pobaltskými štátmi, Rumunskom, Mad'arskom, Gréckom, Slovenskom, Českom a Portugalskom. Česko a Slovensko mali síce lepšie ekonomické predpoklady na rozvoj elektromobility ako ostatné krajiny V4, napriek tomu v roku 2018 dosahovali nižšiu intenzitu elektromobility ako Pol'sko a Mad'arsko.

Získané lineárne nezávislé faktory sú vhodným vstupom do zhlukovej analýzy. Pri využití Wardovej metódy je jej výsledkom dendrogram na obr. 4. Ten je doplnený o teplotné mapy 1. faktora (intenzita elektromobility) a 2. faktora (ekonomické predpoklady na rozvoj elektromobility), prostredníctvom ktorých budeme zhluky interpretovat'.

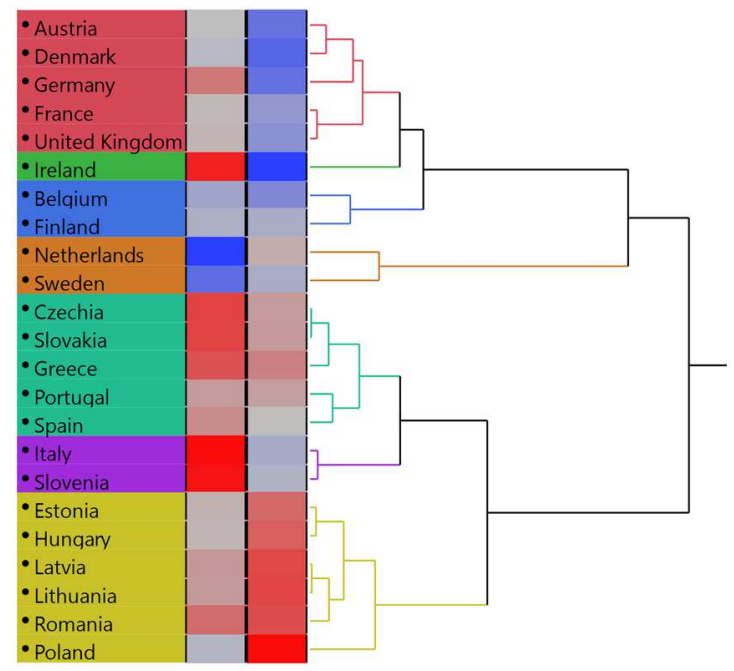

Obr. 4. Dendrogram zhlukov vybraných krajín EÚ z hl’adiska elektromobility v roku 2018 Zdroj: Eurostat (2020) a ACEA (2019a), vlastné spracovanie v SAS JMP.

1. (červený) zhluk tvorí pät' krajín (Rakúsko, Dánsko, Nemecko, Francúzsko a Spojené král'ovstvo), ktorý je charakterizovaný vel'mi dobrými ekonomickými predpokladmi na rozvoj elektromobility (2. faktor). S výnimkou Nemecka mal tento zhluk v roku 2018 po krajinách Beneluxu a krajinách Škandinávskeho polostrova (vrátane Fínska) najvyššiu intenzitu elektromobility v kategórii osobných automobilov.

2. (zelený) zhluk je tvorený len Írskom, ktoré je vel'mi špecifické, pretože v roku 2018 malo najlepšie ekonomické predpoklady na rozvoj elektromobility, ale spolu s krajinami 6. zhluku dosiahlo najnižšiu intenzitu elektromobility.

3. (modrý) a 4. (oranžový) zhluk sú tvorené krajinami Beneluxu a krajinami Škandinávskeho polostrova (okrem Nórska, ktoré nebolo zahrnuté do analýzy). V roku 2018 evidovali krajiny týchto zhlukov priemerné až nadpriemerne dobré predpoklady na rozvoj elektromobility a dosahovali v nej najlepšie výsledky. Atri- 
bút, v ktorom sa uvedené dva zhluky líšia, je intenzita elektromobility, ktorá bola v roku 2018 v 4. zhluku (Holandsko a Švédsko) výrazne vyššia ako v 3. zhluku (Belgicko a Fínsko). Musíme zdôraznit', že v obidvoch zhlukoch bola intenzita elektromobility signifikantne vyššia ako v ostatných zhlukoch.

Prvé štyri sú tvorené krajinami západnej a severnej Európy, ktoré mali v roku 2018 vo všeobecnosti nadpriemerne dobré predpoklady na rozvoj elektromobility a s výnimkou Írska a Nemecka dosiahli priemernú a v prípade krajín Beneluxu a krajín Škandinávskeho polostrova nadpriemernú intenzitu elektromobility. Ostatné tri zhluky zahŕňajú krajiny južnej Európy (Grécko, Portugalsko, Španielsko a Taliansko), krajiny strednej Európy (krajiny V4 a Slovinsko) a pobaltské krajiny spolu s Rumunskom.

V krajinách 5. (tyrkysového) zhluku (Česko, Slovensko, Grécko, Portugalsko a Španielsko) sme kvantifikovali podpriemerné ekonomické predpoklady na rozvoj elektromobility, ako aj podpriemernú intenzitu elektromobility. Cesko a Slovensko mali z krajín 5. zhluku najnižšiu intenzitu elektromobility a výrazne sa približovali ku krajinám 6. zhluku, ktorý dosiahol v tomto smere najhoršie výsledky.

6. (fialový) zhluk vykazuje najväčšiu homogenitu. Taliansko a Slovinsko, ktoré tvoria tento zhluk, mali v roku 2018 síce ekonomické predpoklady na rozvoj elektromobility na priemernej úrovni, ale dosiahli najnižšiu intenzitu elektromobility.

7. (žltý) zhluk je najpočetnejší a tvorí ho šest' krajín (tri pobaltské štáty, Pol'sko, Mad'arsko a Rumunsko). Charakterizujú ho slabé ekonomické predpoklady na rozvoj elektromobility a intenzita elektromobility na podpriemernej (Litva, Lotyšsko a Rumunsko) až priemernej úrovni (Pol'sko, Estónsko a Mad’arsko).

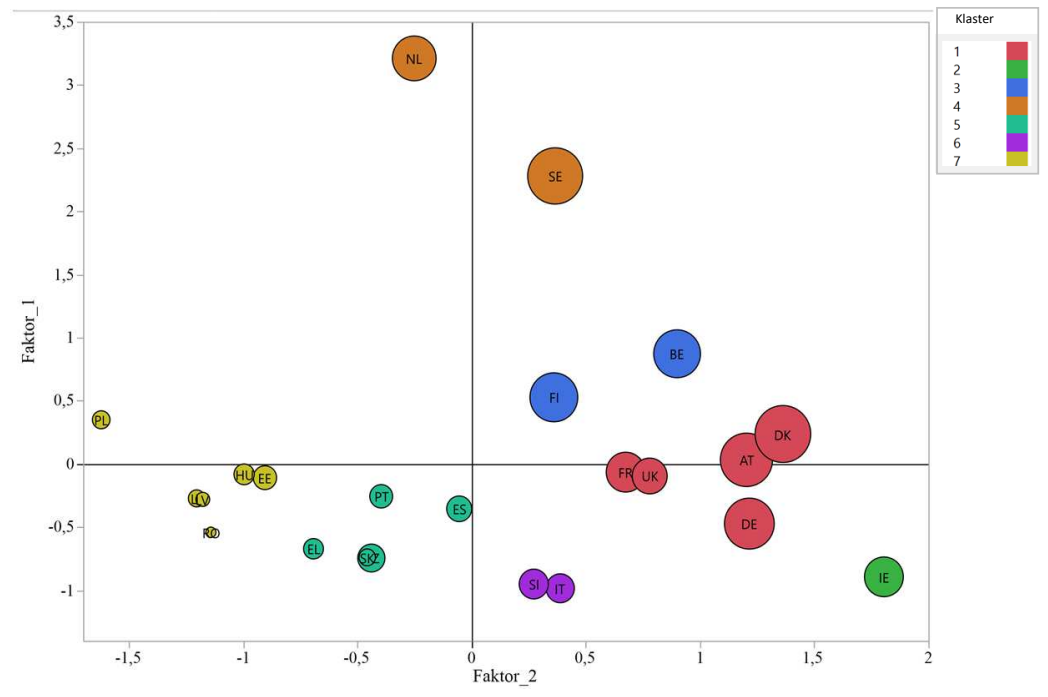

Obr. 5. Bodový diagram intenzity elektromobility (os Y; 1. faktor) a ekonomických predpokladov na rozvoj elektromobility (os X; 2. faktor) vo vybraných krajinách EÚ v roku 2018

Legenda: vel'kost' kruhu udáva výdavky na výskum a vývoj.

Zdroj: Eurostat (2020) a ACEA (2019a), vlastné spracovanie v SAS JMP. 
Na základe výsledkov faktorovej a zhlukovej analýzy posúdime, ktoré krajiny do roku 2018 využili svoju ekonomickú situáciu na rozvoj elektromobility lepšie a ktoré horšie. Na obr. 5 súradnicové osi rozdel'ujú grafické pole na štyri kvadranty (číslované $\mathrm{v}$ protismere pohybu hodinových ručičiek):

1. kvadrant (kladné hodnoty obidvoch faktorov) je charakterizovaný nadpriemernými ekonomickými predpokladmi na rozvoj elektromobility a nadpriemernou intenzitou elektromobility,

2. kvadrant (kladné hodnoty 1. faktora a záporné hodnoty 2. faktora) zahŕňa len Holandsko a Pol'sko a charakterizuje ho nadpriemerne vysoká intenzita elektromobility napriek podpriemerným ekonomickým predpokladom,

3. kvadrant (záporné hodnoty obidvoch faktorov) zahŕn̆a krajiny, v ktorých v roku 2018 boli aj ekonomické predpoklady a aj intenzita elektromobility na podpriemernej úrovni,

4. kvadrant (záporné hodnoty 1. faktora a kladné hodnoty 2. faktora) je charakterizovaný nadpriemerne dobrými ekonomickými predpokladmi, ktoré sa však $\mathrm{v}$ dostatočnej miere doposial' neprejavili v elektromobilite.

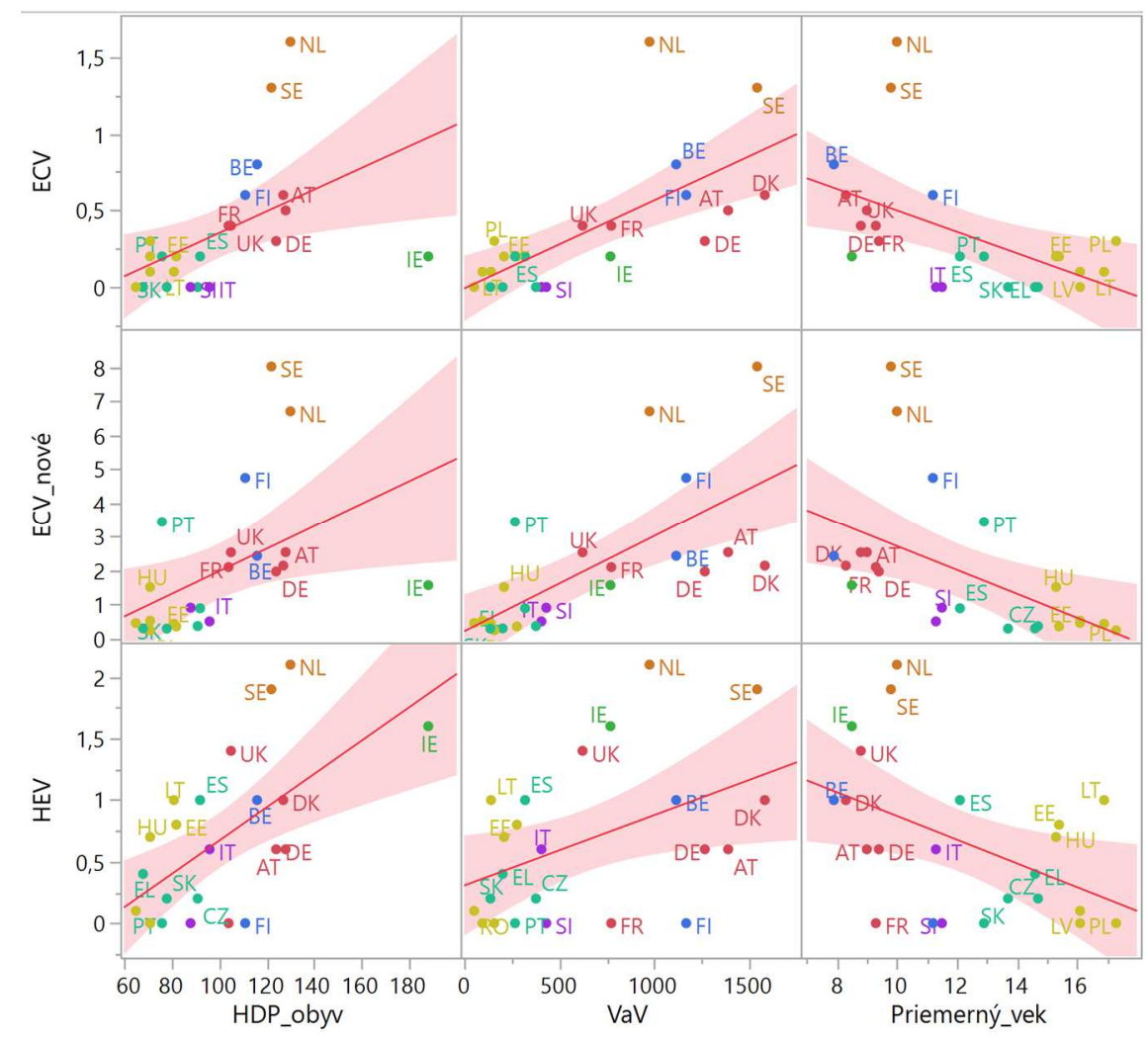

Obr. 6. Matica bodových diagramov medzi vybranými ukazovatel'mi charakterizujúcimi intenzitu elektromobility (os y; ukazovatele $H E V, E C V$ nové a $E C V$ ) a charakterizujúcimi ekonomické predpoklady na rozvoj elektromobility (os $x ; H D P$ obyv, $V a V$

a Priemerný_vek) vo vybraných krajinách EÚ v roku $2 \overline{018}$

Zdroj: Eurostat (2020) a ACEA (2019a), vlastné spracovanie v SAS JMP. 
Z obr. 5 je zrejmá podobnost' krajín spadajúcich do jedného zhluku. Postsocialistické krajiny zo strednej a východnej Európy zahrnuté do žltého a tyrkysováho zhluku sú v 3. kvadrante. Výnimkou je Pol'sko, ktoré vykazuje mierne nadpriemernú intenzitu elektromobility. Z analyzovaných postsocialistických krajín sa do 3. kvadrantu nedostalo ešte Slovinsko, ktoré patrí do fialového zhluku umiestneného v 4. kvadrante. Pre krajiny tohto kvadrantu sú charakteristické nadpriemerne dobré ekonomické predpoklady, ktoré sa však doposial' neprejavili v očakávanej miere v intenzite elektromobility. Štvrtý kvadrant zahŕňa popri krajinách fialového zhluku aj Írsko a väčšinu krajín červeného zhluku. Napriek tomu, že Dánsko a Rakúsko dosiahli kladné hodnoty 1. faktora a dostali sa do 1. kvadrantu, nemôžeme tvrdit', že do roku 2018 svoje dobré ekonomické predpoklady adekvátne využili na elektromobilitu.

Za úspešné krajiny v oblasti elektromobility môžeme považovat' tie, ktoré sa nachádzajú nad osou 1. a 3. kvadrantu a súčasne dosiahli pozoruhodnú intenzitu elektromobility. Tieto podmienky spĺn̆ajú len krajiny oranžového zhluku (Holandsko a Švédsko). Graf na obr. 5 zachytáva aj výdavky krajín na výskum a vývoj (prepočítané na osobu) prostredníctvom vel'kosti bublín. Krajiny severnej a západnej Európy začlenené do prvých štyroch zhlukov (červený, zelený, modrý a oranžový zhluk) majú výrazne vyššie relatívne výdavky na výskum a vývoj ako postsocialistické krajiny EÚ a krajiny južnej Európy. Poznamenajme ešte, že v oblasti elektromobility vykazujú najväčšiu podobnost' Česko so Slovenskom a Lotyšsko s Litvou, čo potvrdzuje dendrogram na obr. 4, ale aj prekrývanie týchto dvojíc krajín na obr. 5.

Pozrime sa na vzt'ahy medzi parciálnymi ukazovatel'mi ( $E C V, E C V$ nové a $H E V$ ), ktoré sa relevantne podiel’ali na kreovaní 1 . faktora, a parciálnymi ukazovatel'mi (HDP_obyv, VaV a Priemerný_vek), ktoré signifikantne determinovali 2. faktor. Vo všetkých deviatich grafoch na obr. 6 sa potvrdilo, že krajiny severnej a západnej Európy (krajiny červeného, modrého, oranžového a zelẹného zhluku) sa v roku 2018 významne odlišovali od postsocialistických krajín EÚ a od krajín južnej Európy (krajiny žltého, tyrkysového a fialového zhluku). Krajiny severnej a západnej Európy mali vyšší HDP (na obyvatel’a v parite kúpnej sily), vyššie výdavky na výskum a vývoj (na obyvatel'a) a nižší priemerný vek osobných automobilov. Tieto tri ukazovatele podl'a tab. 2 na hladine významnosti 0,05 štatisticky významne korelovali s ukazovatel'mi $E C V, E C V$ nové a $H E V$. Tieto korelácie pre premennú $H D P \_o b y v$ a $V a V$ boli priame lineárne, čo vystihujú aj rastúce vyrovnávajúce priamky na obr. 6 a pre premennú Priemerný_vek sme podl'a očakávania zistili nepriame korelácie.

V severnej a západnej Európe je v porovnaní s postsocialistickými krajinami EÚ a krajinami južnej Európy vyšší celkový podiel ECV a podiel ECV medzi novými automobilmi (výnimkou je Portugalsko). V prípade podielu HEV už dominancia severnej a západnej Európy nie je taká jednoznačná. Aj ked' je v krajinách EÚ počet HEV vyšší ako počet ECV, tak v roku 2018 len štyri krajiny evidovali podiel HEV nad $1 \%$ (Holandsko, Švédsko, Írsko a Spojené královstvo).

V roku 2018 bol podiel ECV medzi všetkými osobnými vozidlami vyšší ako $1 \%$ len v krajinách oranžového zhluku (Holandsko a Švédsko). V mnohých krajinách (vrátane Česka a Slovenska) bol tento podiel takmer nulový. Pokial ide o ECV medzi novými osobnými vozidlami, tak podiel nad $1 \%$ dosiahla väčšina posudzovaných krajín (12 z 23), ale podiel nad $5 \%$ bol opät' len v krajinách oranžového zhluku (Švédsko a Holandsko). V Nemecku, Spojenom král'ovstve a vo 
Francúzsku, teda v krajinách, ktoré v roku 2018 mali najväčší automobilový trh v rámci EÚ-28 (3,4 mil., 2,4 mil. a 2,2 mil. predaných áut), bol podiel ECV medzi novými osobnými vozidlami na úrovni 2 až 2,5\%.

Aj ked' Švédsko a Holandsko dosahujú signifikantne lepšie výsledky v elektromobilite ako zvyšné analyzované krajiny, tak stále výrazne zaostávajú za Nórskom, ktoré v roku 2018 evidovalo medzi všetkými osobnými automobilmi 10,7 \% ECV a 3,9\% HEV. Dokonca nové osobné automobily so spal'ovacím motorom boli v Nórsku v menšine, ked' ECV a HEV spolu tvorili až 3/5 všetkých nových osobných automobilov. Vo Fínsku, Švédsku a Holandsku bol tento podiel pod $15 \%$ a v ostatných krajinách Európy bol pod 10 \%. Najnižší podiel ECV a HEV medzi novými osobnými vozidlami mali Česko a Slovensko.

Medzi všetkými osobnými automobilmi, ako aj medzi novými osobnými automobilmi je podiel ECV v najtesnejšom vzt'ahu s výdavkami na výskum a vývoj (pozri obr. 2 a tab. 2). Regresné priamky pre tieto závislosti znázornené na obr. 6 majú rovnice:

$$
\begin{aligned}
& \widehat{E C V}=-0,009334+0,000575 \cdot \mathrm{VaV} \\
& \overline{E C V_{-} \text {nové }}=0,2189+0,0028 \cdot \mathrm{VaV}
\end{aligned}
$$

$\mathrm{V}$ obidvoch prípadoch ide o stredne silnú priamu koreláciu (obr. 2). Z odhadu regresného koeficientu s hodnotou 0,000575 môžeme konštatovat', že krajiny ktoré mali v roku 2018 výdavky na výskum a vývoj o 1000 eur na obyvatel'a vyššie, dosiahli v uvedenom roku v priemere o 0,575 p. b. vyšší podiel ECV, ak hovoríme o všetkých osobných vozidlách. Ak uvažujeme o nových osobných automobiloch, tak nárast výdavkov na výskum a vývoj o 1000 eur korešponduje s priemerným nárastom podielu ECV až o 2,8 p. b.

\section{DISKUSIA A ZÁVER}

Článok poskytuje hodnotenie 23 krajín EÚ-28 z hl'adiska elektromobility na základe prierezových údajov za rok 2018, pričom berie do úvahy jej vzt’ah s hospodárskymi predpokladmi na rozvoj elektromobility a so znečistením ovzdušia emisiami skleníkových plynov v týchto krajinách. Prostredníctvom korelačnej analýzy a analýzy vhodnosti vstupných premenných pre faktorovú analýzu sme zistili, že podl'a aktuálnych agregovaných štatistík z krajín EÚ nie je preukázatel'né, že vyššia penetrácia elektricky nabíjatel'ných vozidiel a hybridných elektrických vozidiel v osobnej doprave je spojená s nižším znečistením ovzdušia emisiami skleníkových plynov. To však nie je v rozpore s vedeckými štúdiami (napr. Moro a Lonza 2018 a Tucki et al. 2019), ktoré ukázali potenciálne pozitívne účinky elektromobility na redukciu skleníkových plynov. Naše analýzy len potvrdzujú, že elektromobilita zatial' nepriniesla preukázatel'né zlepšenie kvality ovzdušia, čo môže byt' spôsobené tým, že nízka intenzita elektromobility, aká je v súčasnosti v EÚ, nemá zásadný vplyv na redukciu emisií skleníkových plynov. Tento efekt môže byt' zatienený aj inými skutočnost’ami, ako napríklad nárastom predaja SUV, ktoré majú vyššiu produkciu $\mathrm{CO}_{2} / \mathrm{km}$ (Transport and Environment 2019). Navyše, priaznivé efekty elektromobility na životné prostredie závisia aj od d'alších faktorov, a to hlavne od toho, do akej miery je zdroj elektrickej energie „ekologicky čistý“" (Casals et al. 2016). 
Z uvedeného dôvodu sa d'alší výskum zúžil na posúdenie vzt'ahu medzi ekonomickými predpokladmi krajín EÚ a intenzitou elektromobility. Aby sme získali čo najkomplexnejší obraz o tomto vzt'ahu, tak sme prostredníctvom faktorovej analýzy z pôvodných ukazovatel'ov vytvorili dva lineárne nezávislé faktory, pričom 1. faktor charakterizoval intenzitu elektromobility a 2. faktor reprezentoval ekonomické predpoklady na rozvoj elektromobility. Faktor ekonomických predpokladov na rozvoj elektromobility bol zásadne determinovaný ukazovatel'mi, ako sú HDP na obyvatel'a, výdavky na výskum a vývoj a priemerný vek osobných automobilov. Ked'že HDP a výdavky na výskum a vývoj (v obidvoch prípadoch prepočítané na obyvatel'a) sú vo vzájomnom priamom vzt'ahu a priemerný vek osobných automobilov v príslušnej krajine s nimi vykazuje nepriamu koreláciu, tak prvé dva ukazovatele sa na tvorbe faktora pre dimenziu ekonomických predpokladov podiel'ali priamo (kladné váhy) a priemerný vek osobných automobilov zasa nepriamo (záporná váha). Každý z týchto ukazovatel'ov bol v roku 2018 signifikantne korelovaný s podielom elektricky nabíjatel'ných vozidiel a s podielom hybridných elektrických vozidiel v celej skupine osobných automobilov, ale aj s podielom elektricky nabíjatel'ných vozidiel medzi novými zaregistrovanými osobnými autami. Uvedené tri podielové ukazovatele významne kreovali faktor intenzity elektromobility.

Korelačná analýza, ale aj na ňu nadväzujúca faktorová analýza a zhluková analýza jednoznačne potvrdili, že ekonomická vyspelost' krajiny, či už charakterizovaná uvedenými tromi parciálnymi ukazovatel'mi, alebo z nich vytvoreným faktorom, podstatne ovplyvňuje intenzitu elektromobility. Tieto zistenia sú v súlade $\mathrm{s}$ tvrdením Yonga a Parka (2017), že v krajinách s vysokým ekonomickým statusom je ovel'a pravdepodobnejšie osvojenie si elektromobility. Yong a Park (2017) však poukazujú na to, že samotná ekonomická vyspelost' krajiny nemusí postačovat', pretože dôležitú úlohu zohráva podpora elektromobility formou oslobodenia od daní alebo formou dotácií na nákup elektrických vozidiel podstatný vplyv má aj nabíjacia infraštruktúra. $V$ našej analýze sme s rozvojom infraštruktúry nabíjacích staníc neuvažovali, pretože dostupné štatistiky o počte nabíjacích staníc neinformujú o tom, aké regióny a akú čast' populácie príslušnej krajiny táto infraštruktúra pokrýva. Táto informácia je pritom dôležitá, pretože podl'a Mortona et al. (2018) má rozvoj infraštruktúry lokálny vplyv, čo znamená, že registrácia elektrických vozidiel v danom regióne nie je preukázatel'ne ovplyvnená dostupnou infraštruktúrou nabíjacích staníc v susedných regiónoch. Poznamenajme, že empirické výskumy (napr. Hanzič et al. 2018) potvrdzujú, že podobne ako intenzita elektromobility, aj rozvoj infraštruktúry nabíjacích staníc ide ruka v ruke s hospodárskym rozvojom krajiny.

Ked'že je intenzita elektromobility preukázatel'ne asociovaná s ekonomickými predpokladmi na jej rozvoj, tak sme analyzované krajiny EÚ-28 podrobili zhlukovej analýze vychádzajúcej z uvedených dvoch faktorov charakterizujúcich dimenziu elektromobility a dimenziu ekonomických predpokladov. Takto sme odhalili sedem relatívne homogénnych zhlukov krajín z pohl'adu posudzovaných dimenzií a identifikovali sme ich špecifiká. Interpretácia zhlukov prostredníctvom faktorov potvrdila, že v severnej a západnej Európe je v porovnaní s postsocialistickými krajinami EÚ a s krajinami južnej Európy vyššia intenzita elektromobility. Postsocialistické krajiny EU a krajiny južnej Európy mali v roku 2018 podpriemerné ekonomické predpoklady na rozvoj elektromobility a aj nízku intenzitu elektromobility. Tento stav môže byt' ovplyvnený aj skutočnost'ou, že v roku $2018 \mathrm{v}$ uvedených častiach Európy poskytovali vlády štátov dotácie na nákup EV len v Portugalsku, 
Rumunsku, Slovinsku a na Malte (Tucki at al. 2019). Aj ked' v roku 2019 viaceré krajiny prijali opatrenia na podporu elektromobility, tak stále zostali štyri postsocialistické krajiny, ktoré ako jediné v rámci EÚ-28 nemali daňové výhody a ani finančné stimuly na podporu elektromobility. Ide o Estónsko, Chorvátsko, Litvu a Pol'sko (ACEA 2019b).

Z našich analýz vyplýva, že najhoršie svoje ekonomické východiská na rozvoj elektromobility využilo Irsko, ktoré v roku 2018 malo spolu s Talianskom a Slovinskom najnižšiu intenzitu elektromobility, a to aj napriek tomu, že v Írsku a Slovinsku sa poskytovala finančná dotácia pri kúpe EV a vlády všetkých troch uvedených krajín (vrátane Talianska) zaviedli daňové výhody a nefinančné stimuly pre EV.

Napriek ovel’a lepším ekonomickým predpokladom, ani väčšina krajín západnej Európy zatial' nedosiahla výrazný stupeň elektromobility. Do tejto skupiny zarad'ujeme aj najväčšie automobilové trhy v rámci EÚ-28 - Nemecko, Spojené královstvo a Francúzsko, ktoré majú pomerne vysoký počet nabíjacích staníc (v roku 2018 mali spolu približne 1/2 nabíjacích staníc v EÚ-28) a majú zavedené nákupné stimuly pre EV.

Dobrá ekonomická situácia sa relatívne úspešne pretavila do elektromobility vo Fínsku a Belgicku a najmä vo Švédsku a Holandsku. Zaujímavost’ou je, že Holandsko - na rozdiel od ostatných troch krajín - nemá stimuly na nákup EV, ale má najväčší počet nabíjacích staníc v EÚ (viac ako $1 / 4$ všetkých nabíjacích staníc v EÚ-28). V našej analýze sme síce nebrali do úvahy Nórsko, ale na základe dostupných štatistík a podl'a mnohých prác, na ktoré v článku upriamujeme pozornost', je Nórsko absolútne najpokrokovejšie v predmetnej oblasti. Náš výskum teda potvrdil jednoznačnú dominanciu krajín Škandinávskeho polostrova a štátov Beneluxu v oblasti elektromobility.

Napriek tomu, že 1. faktor, ktorý bol výsledkom faktorovej analýzy, vytvára ucelenejší obraz o ekonomických predpokladoch na rozvoj elektromobility ako parciálne ukazovatele, ktoré sa na jeho tvorbe podiel'ali, pozreli sme sa aj na vzt'ahy medzi parciálnymi ukazovatel'mi 1. faktora (faktor ekonomických predpokladov) a parciálnymi ukazovatel'mi 2. faktora (faktor intenzity elektromobility). Regresná a korelačná analýza ukázali, že medzi všetkými osobnými automobilmi, ako aj medzi novými osobnými automobilmi je podiel ECV v najtesnejšom vzt’ahu s výdavkami na výskum a vývoj. Tento ukazovatel' sa navyše ako jediný signifikantne podiel'al na tvorbe obidvoch faktorov, čo znamená, že výdavky na výskum a vývoj sú úzko späté nielen $\mathrm{s}$ faktorom ekonomických predpokladov na rozvoj elektromobility, ale aj $\mathrm{s}$ faktorom charakterizujúcim jej intenzitu. Naše analýzy potvrdili signifikantnú pozitívnu koreláciu medzi výdavkami krajín na výskum a vývoj a penetráciou ECV do osobnej dopravy. V súčasnosti je nárast výdavkov na výskum a vývoj o 1000 eur obyvatel’a spojený spriemerným nárastom podielu ECV medzi osobnými vozidlami o 0,5 p. b. a v prípade podielu ECV medzi novými vozidlami je tento efekt ešte pät'násobne väčší.

Vplyv elektromobility na redukciu emisií skleníkových plynov nie je v súčasnosti na národných úrovniach krajín EÚ empiricky preukázatel'ný, avšak veríme, že $s$ nárastom intenzity elektromobility sa jej pozitívny vplyv v dohl'adnom čase prejaví a bude čitatel'ný z agregovaných štatistík. V rámci EU majú viaceré krajiny ekonomické predpoklady na intenzívnejšiu elektromobilitu, avšak výrazne zaostávajú za lídrami v tejto oblasti, ktorými sú štáty Škandinávskeho polostrova a Bene- 
luxu. Aj ked' intenzita elektromobility je významne determinovaná ekonomickou situáciou, sú tu aj d’alšie faktory, ktoré treba „,nastavit““ tak, aby podporili elektromobilitu, či už hovoríme o ekologickom povedomí, daňových, finančných a nefinančných stimuloch alebo o infraštruktúre nabíjacích staníc. Disparity medzi krajinami treba vziat' do úvahy v kontexte ekonomických predpokladov, ktoré zväčša v krátkom časovom horizonte nemožno zásadne zmenit', ale vo výrazne kratšom čase sa dajú zaviest' stimuly alebo aj vybudovat' vhodná nabíjacia infraštruktúra. $\mathrm{Na}$ základe našej kvantitatívnej analýzy sú identifikované krajiny, ktoré sú pri porovnatel'nej ekonomickej situácii v oblasti elektromobility úspešnejšie a nich by mali hl'adat' inšpiráciu menej úspešné krajiny.

Viacrozmerné štatistické metódy, ktoré boli využité v článku, splnili svoj účel, ale musíme zdôraznit', že ich efektivita by sa ešte zvýšila, ak by boli analýzy realizované na menších územných jednotkách (napr. NUTS 2 alebo NUTS 3). Na takýchto územných jednotkách by bolo vhodné kvantifikovat' aj vplyv d'alších faktorov, ako napr. infraštruktúry nabíjacích staníc, avšak príslušné inštitúcie alebo organizácie (napr. Eurostat alebo ACEA) štatistiky o elektromobilite na takomto územnom členení v súčasnosti nesledujú.

Príspevok vznikol ako čiastkový výstup projektu APVV SK-SRB-18-0009 Optimalizácia logistických procesov s využitím elektromobilov a ich IKT riešenia a projektu VEGA 1/0339/20 Využitie skrytého Markovovho modelu vo finančnom modelovaní.

\section{LITERATÚRA}

ACEA (2019a). ACEA Report: Vehicles in use - Europe 2019. (European Automobile Manufacturers' Association).

ACEA (2019b). Interactive map: Electric vehicle purchase incentives per country in Europe (2019 update). (European Automobile Manufacturers' Association), [Online]. Dostupné na: https://www.acea.be/statistics/article/interactive-map-electric-vehicle-incentives-per -country-in-europe-2018 [cit: 29-12-2020].

AJANOVIC, A., HAAS, R. (2016). Dissemination of electric vehicles in urban areas: Major factors for success. Energy, 115, 1451-1458. DOI: http://dx.doi.org/10.1016/ j.energy.2016.05.040.

ANDERSON, T. R., HAWKINS, E., JONES, P. D. (2016). CO2, the greenhouse effect and global warming: from the pioneering work of Arrhenius and Calendar to today's Earth System Models. Endeavou, 40, 178-187. DOI: https://doi.org/10.1016/j.endeavour. 2016.07.002.

BROADBENT, G. H., DROZDZEWSKI, D., METTERNICHT, G. (2018). Electric vehicle adoption: An analysis of best practice and pitfalls for policy making from experiences of Europe and the US. Geography compass, 12(2), 1-15. DOI: https://doi.org/10.1111/ gec3.12358.

CASALS, L., MARTINEZ-LASERNA, E., AMANTE, B., NIETO, N. (2016). Sustainability analysis of the electric vehicle use in Europe for $\mathrm{CO}_{2}$ emissions reduction. Journal of cleaner production, 127, 425-437. DOI: https://doi.org/10.1016/j.jclepro. 2016.03.120.

CHRISTIDIS, P., FOCAS, C. (2019). Factors affecting the uptake of hybrid and electric vehicles in the European Union. Energies, 12, (18), 3414. DOI: https://doi.org/10.3390/ en12183414.

EASAC (2019). Decarbonisation of transport: options and challenges. EASAC policy report 37. Halle (German National Academy of Sciences Leopoldina).

EEA (2019). Greenhouse gas emissions from transport in Europe. Copenhagen (European Environment Agency). 
EUROPEAN COMMISSION (2019). Reducing $\mathrm{CO}_{2}$ emissions from passenger cars, [Online]. Dostupné na: https://ec.europa.eu/clima/policies/transport/vehicles/cars en [cit: 14-3-2020].

EUROSTAT (2020). Data, [Online]. Dostupné na: https://ec.europa.eu/eurostat/web/main/ data/database [cit: 9-2-2020].

GRYPARIS, E., PAPADOPOUlOS, P., LELIGOU, H. C., PSOMOPOULOS, C. S. (2020). Electricity demand and carbon emission in power generation under high penetration of electric vehicles. A European Union perspective. Energy Reports, 6, 475-486. DOI: https://doi.org/10.1016/j.egyr.2020.09.025.

HAIR, J., BLACK, W., BABIN, B., ANDERSON, R. (2018). Multivariate data analysis, 8 th ed. New York (Cengage Learning EMEA).

HANŽIČ, K., MARKSEL, M., BOŽIČNIK, S. (2018). Interdependence between GDP and electric vehicles' charging infrastructure in the EU. In Seme, S., Hadžiselimović, M., Štumberger, B., eds. 7th International Symposium on Applied Electromagnetics: Conference Proceedings. Maribor (University of Maribor Press), pp. 97-101. DOI: https:// doi.org/10.18690/978-961-286-241-1.12.

LÉVAY, P. Z., DROSSINOS, Y., THIEL, C. (2017). The effect of fiscal incentives on market penetration of electric vehicles: A pairwise comparison of total cost of ownership. Energy Policy, 105, 524-533. DOI: https://doi.org/10.1016/j.enpol.2017.02.054.

LIONELLO, P., SCARASCIA, L. (2018). The relation between climate change in the Mediterranean region and global warming. Regional Environmental Change, 18, 14811493. DOI: https://doi.org/10.1007/s10113-018-1290-1.

LÖSTER, T., PAVELKA, T., eds. (2013). Evaluating of the results of clustering in practical economic tasks. In 7th International Days of Statistics and Economics, Conference proceedings. Prague (University of Economics in Prague), pp. 804-818.

LUBYOVÁ, M., VOJTKOVÁ, M. (2014). Analýza miery atraktívnosti národných ekonomík pre zahraničných investorov v novom globalizovanom prostredí. Ekonomický časopis, 62, 557-578.

MORO, A., LONZA, L. (2018). Electricity carbon intensity in European Member States: Impacts on GHG emissions of electric vehicles. Transportation Research Part D: Transport and Environment, 64, 5-14. DOI: https://doi.org/10.1016/j.trd.2017.07.012.

MORTON, C., ANABLE, J., YEBOAH, G., COTTRILL, C. (2018). The spatial pattern of demand in the early market for electric vehicles: Evidence from the United Kingdom. Journal of Transport Geography, 72, 119-130. DOI: https://doi.org/10.1016/ j.jtrangeo.2018.08.020.

MÜNZEL, C., PLÖTZ, P., SPREI, F., GNANN, T. (2019). How large is the effect of financial incentives on electric vehicle sales? - A global review and European analysis. Energy Economics, 84, 1-21. DOI: https://doi.org/10.1016/j.eneco.2019.104493.

NOEL, L., DE RUBENS, G. Z., KESTER, J., SOVACOOL, B. K. (2020). Understanding the socio-technical nexus of Nordic electric vehicle (EV) barriers: A qualitative discussion of range, price, charging and knowledge. Energy Policy, 138, 1-15. DOI: https:// doi.org/10.1016/j.enpol.2020.111292.

ORTAR, N., RYGHAUG, M. (2019). Should all cars be electric by 2025 ? The electric car debate in Europe. Sustainability, 11, 1-16. DOI: https://doi.org/10.3390/su11071868.

REIFF, M., SURMANOVÁ, K, BALCERZAK, A. P., PIETRZAK, M. B. (2016). Multiple criteria analysis of European Union agriculture. Journal of International Studies, 9(3), 62-74. DOI: https://doi.org/10.14254/2071-8330.2016/9-3/5.

REIFF, M., IVANIČOVÁ, Z., SURMANOVÁ, K. (2018). Cluster analysis of selected world development indicators in the fields of agriculture and the food industry in European Union countries. A gricultural Economics, 64, 197-205. DOI: https://doi.org/ 10.17221/198/2016-AGRICECON.

SOVACOOL, B. K., KESTER, J., NOEL, L., de RUBENS, G. Z. (2019). Income, political affiliation, urbanism and geography in stated preferences for electric vehicles (EVs) and vehicle-to-grid (V2G) technologies in Northern Europe. Journal of Transport Geography, 78, 214-229. DOI: https://doi.org/10.1016/j.jtrangeo.2019.06.006. 
SZULEJKO, J. E., KUMAR, P., DEEP, A., KIM, K. H. (2017). Global warming projections to 2100 using simple $\mathrm{CO} 2$ greenhouse gas modelling and comments on $\mathrm{CO}_{2}$ climate sensitivity factor. Atmospheric Pollution Research, 8, 136-140. DOI: http:// dx.doi.org/10.1016/j.apr.2016.08.002.

ŠOLTÉS, E. (2019). Regresná a korelačná analýza s aplikáciami v softvéri SAS. Bratislava (LetraEdu).

THIEL, C., JULEA, A., IBORRA, B. A., de MIGUEL ECHEVARRIA, N., PEDUZZI, E., PISONI, E., VILCHEZ, J. J. G., KRAUSE, J. (2019). Assessing the impacts of electric vehicle recharging infrastructure deployment efforts in the European Union. Energies, 12, 1-23. DOI: https://doi.org/10.3390/en12122409.

TRANSPORT AND ENVIRONMENT (2019). Mission possible: How car makers can reach their 2021 CO2 targets and avoid fines. Brussel (European Federation for Transport and Environment AISBL).

TRANSPORT AND ENVIRONMENT (2020). Recharge EU: How many charge points will Europe and its Members States need in the 2020s. Brussel (European Federation for Transport and Environment AISBL).

TUCKI, K., ORYNYCZ, O., ŚWIĆ, A., MITORAJ-WOJTANEK, M. (2019). The development of electromobility in Poland and EU States as a tool for management of $\mathrm{CO}_{2}$ emissions. Energies, 12, (15), 2942. DOI: https://doi.org/10.3390/en12152942.

VILCHEZ, J. J. G., THIEl, C. (2019). The effect of reducing electric car purchase incentives in the European Union. World Electric Vehicle Journal, 10(4), 64. DOI: https:// doi.org/10.3390/wevj10040064.

VOJTKOVÁ, M., STANKOVIČOVÁ, I. (2020). Viacrozmerné štatistické metódy s aplikáciami v softvéri SAS. Bratislava (LetraEdu).

YAZGAN, Ş., YALÇINKAYA, Ö. (2018). The effects of research and development (R\&D) investments on sustainable economic growth: Evidence from OECD countries (1996 - 2015). Review of Economic Perspectives, 18, 3-23. DOI: https://doi.org/ 10.1515/revecp-2018-0001.

YONG, T., PARK, C. (2017). A qualitative comparative analysis on factors affecting the deployment of electric vehicles. Energy Procedia, 128, 497-503. DOI: https://doi.org/ 10.1016/j.egypro.2017.09.066.

\author{
Erik Šoltés, Ivan Brezina, Juraj Pekár
}

\title{
ELECTROMOBILITY AND ITS RELATIONSHIP WITH THE ECONOMIC DEVELOPMENT AND AIR POLLUTION IN THE EU AREA
}

Currently, more than $25 \%$ of greenhouse gas (GHG) emissions within the European Union come from transport, transport is also the only primary economic sector in which GHG emissions have increased since 1990. A major GHG is carbon dioxide, so one of the most important strategies for the reduction of GHG emissions is the decarbonization of transport. A progressive trend in the process of decarbonization of transport is electromobility. There are promising prospects that this will contribute to the protection of the environment, to improvements in the health of the population, and an increase in the quality of people's lives. The potential for the positive effects of electromobility has been confirmed by many scientific studies, although there are also some aspects which still need to be addressed concerning ecology, whether it be the recycling of batteries or the production of electricity from renewable sources.

The article provides an assessment of 23 out of EU-28 countries in terms of electromobility based on cross-sectional data from 2018, taking into account their relationship with the economic preconditions for the development of electromobility and air pollution from 
GHG emissions in these countries. The presented results of our research are based on multivariate statistical methods such as correlation analysis, factor analysis, cluster analysis, as well as, to some extent, regression analysis. Through correlation analysis and analysis of the suitability of input variables for factor analysis, we found that according to current aggregated statistics from EU countries, it is not demonstrable that a higher penetration of electrically-chargeable vehicles (ECV) and hybrid electric vehicles (HEV) in passenger transport is associated with lower air pollution from GHG emissions. In the EU, the intensity of electromobility is so low that it does not yet have a significant impact on the reduction of GHG emissions.

We evaluated the relationship between the economic conditions in the EU countries and the intensity of electromobility based on 6 indicators: GDP (at purchasing power parity) per capita, expenditure on R\&D per capita, the average age of passenger cars, ECV share and HEV share among all passenger cars and ECV share among new passenger cars. In order to obtain the most comprehensive view on this relationship, 2 linear independent factors were created from the original indicators through factor analysis, with the 1st factor characterizing the intensity of electromobility and the 2 nd factor representing the economic conditions for the development of electromobility. The correlation analysis of the original indicators, as well as the assessment of the relationship between the factors that were the result of the factor analysis, clearly confirmed that the intensity of electromobility is significantly associated with the economic development of the country. The view of the relationship between the particular dimensions in the EU area is completed with a cluster analysis. It reveals 7 relatively homogeneous clusters of countries from the point of view of the assessed dimensions. To describe the specifics, we use the above mentioned 2 factors characterizing the dimension of the electromobility intensity and the dimension of economic conditions. In Northern and Western Europe, there is a higher intensity of electromobility compared to the post-socialist countries of the EU and the countries of Southern Europe. In 2018, the postsocialist countries of the EU and the countries of Southern Europe had below-average economic preconditions for the development of electromobility and a low intensity of electromobility, while other than these countries the intensity of electromobility badly reflected the economic situation in Slovakia and Czechia. However, its economic potential for the development of electromobility was worst used by Ireland, which also had the lowest intensity of electromobility, as well as Italy and Slovenia, despite the fact that the governments of Ireland and Slovenia provide financial subsidies for the purchase of electric vehicles (EVs) and the governments of all 3 countries (including Italy) introduced tax benefits and non-financial incentives for EVs. Despite significantly better economic prospects, most western European countries (including the largest car markets within the EU-28 - Germany, the United Kingdom and France) have not attained a notable intensity of electromobility. The best results in electromobility have been achieved by the countries of the Scandinavian Peninsula and the Benelux.

Our quantitative analyses have shown that disparities in electromobility within the EU need to be assessed in the context of economic situations. Countries that are less successful in electromobility should naturally seek inspiration from more successful countries. However, this success is significantly influenced by economic conditions that are difficult to change in the short term, therefore less successful countries should seek inspiration not only in the most successful countries but also in those ones that achieved a noticeable intensity of electromobility while having a comparable economic situation. This article identifies which countries have been more successful in the field of electromobility and which have been less successful, with similar economic preconditions for the development of electromobility. In addition, the article lists some other factors, of which, the impact on the intensity of electromobility has been confirmed by other scientific studies. Compared to economic assumptions, these can be favourably adjusted in a much shorter time frame.

Regression and correlation analysis has shown that among all passenger cars, as well as among new passenger cars, the share of ECV is most closely related to R\&D expenditure 
per capita. Currently, an increase in research and development expenditure by $€ 1,000$ is associated with an average increase in the share of ECV among passenger cars by 0.5 percentage points. With regard to the share of ECV among new vehicles, this effect is five times greater.

(c) (i) (S) Article first received: July 2020 
